University of Nebraska - Lincoln

DigitalCommons@University of Nebraska - Lincoln

Agronomy \& Horticulture -- Faculty Publications

Agronomy and Horticulture Department

4-1954

Nature and Place of Transition from True Prairie to Mixed Prairie

J. E. Weaver

University of Nebraska-Lincoln

W. E. Bruner

Follow this and additional works at: https://digitalcommons.unl.edu/agronomyfacpub

Part of the Plant Sciences Commons

Weaver, J. E. and Bruner, W. E., "Nature and Place of Transition from True Prairie to Mixed Prairie" (1954). Agronomy \& Horticulture -- Faculty Publications. 484.

https://digitalcommons.unl.edu/agronomyfacpub/484

This Article is brought to you for free and open access by the Agronomy and Horticulture Department at DigitalCommons@University of Nebraska - Lincoln. It has been accepted for inclusion in Agronomy \& Horticulture -Faculty Publications by an authorized administrator of DigitalCommons@University of Nebraska - Lincoln. 


\title{
NATURE AND PLACE OF TRANSITION FROM TRUE PRAIRIE TO MIXED PRAIRIE
}

\author{
J. E. Weaver and W. E. Bruner \\ University of Nebraska, Lincoln, Nebraska, and Ncbraska State Teachers \\ College, Kearney, Ncbraska
}

\begin{abstract}
As a memorial to Dr. Frederic E. Clements, it is a pleasure to present this paper on the midcontinental grasslands of North America. Born and reared at Lincoln, Nebraska, he developed a remarkable interest in and love for the prairie. He has often stated to the first author that of all the vegetation of North America, he liked the grassland best. Clements was the first to recognize the Mixed Prairie as a distinct plant association and to describe its nature and range and the grouping of the dominants (1920).
\end{abstract}

When one examines the prairies of western Iowa and then proceeds some distance westward, he is impressed by several changes. The vegetation is reduced in height, it becomes less dense, and takes on a distinctly more xeric impress. These changes result from gradually increasing unfavorable water relations as the vegetation of True Prairie gives way to that of Mixed Prairie. Along the Nebraska-Kansas interstate line, for example, the 33-inch annual precipitation near the Missouri River decreases westward at an average rate of about an inch every 15 miles. Conversely, rate of evaporation rapidly increases.

In Nebraska, the transition from True to Mixed Prairie occurs over three types of topography. South of the Platte Valley Lowland it has been traced over the nearly level portion of the Loess Plain Region (Fig.1). Northward, the transition takes place in the greatly dissected Loess Hills and Plains. East of the northern Sandhill Region, it occurs on the Holt-Pierce Plain and Boyd Shale Plain.

\section{Transition in the Loess Plain Region}

In an extensive study of prairie (Weaver and Fitzpatrick 1934), a large number of stations were selected extending from Belleville, Kansas, in Republic County, through the tier of counties lying due northward to Yankton County in South Dakota (Fig. 2). The vegetation at each of these stations was found to be True Prairie. Another lot of stations about 30 miles westward, extending from Mankato in Jewel County, Kansas, northward through Nuckolls, Clay and Hamilton Counties a few miles west of the 98th meridian to the Platte River, was found to represent an area in which transition to Mixed Prairie was clearly beginning. Approximately 70 miles westward, studies were made at Phillipsburg in 1920-1923 (Clements and Weaver 1924), and at Hays, Kansas, from 1930-1935 (Albertson 1937). Later studies were extended northward through Alma and Holdrege, Nebraska (Fig. 2). These investigations showed clearly that here typical Mixed Prairie prevailed. Extensive study of the intervening area, about 50 miles in width, has confirmed that it is here that the transition occurs.

\section{Changes Accompanying the Transition}

Difference in the more mesic prairies of Iowa and Missouri from the more xeric ones westward have been pointed out by Weaver and Fitzpatrick (1934). Height growth in groups of prairies in one area was compared with that of groups in other areas during the same season. For example, in northeastern Kansas and southeastern Nebraska, average height of little bluestem (Andropogon scoparius) ${ }^{1}$ on July 12, 1929. was 13 to 18 inches, which was 5 to 8 inches greater than near Lincoln, Nebraska, five days later. Height growth of foliage of big bluestem (A. gerardi) in three prairies in southeastern Nebraska and Iowa was 21 to 33 inches on August 28-30. This was 8 to 9 inches greater than that at three stations near Lincoln, during August and September. During July 7-12, 1931, little bluestem averaged 7 to 12 inches tall at a group of five stations in southern Nebraska and northern Kansas near the western border of True Prairie. A week later measurements at five stations in west-central Iowa gave averages which were twice as great.

As one proceeded westward toward the transition region the grass became shorter and more mesic species did not extend so far up the slopes. For example, at stations 80 to 110 miles west of the Missouri River, little bluestem was 12 to 14 inches tall on June 26, 1931. But 25 to 35 miles farther west, the height was only 9 to 12 inches two weeks later. Similarly, big bluestem was 15

${ }^{1}$ Nomenclature of grasses follows Hitchcock and Chase (1950); that of other species is according to Britton and Brown (1913) unless other authority is given. 


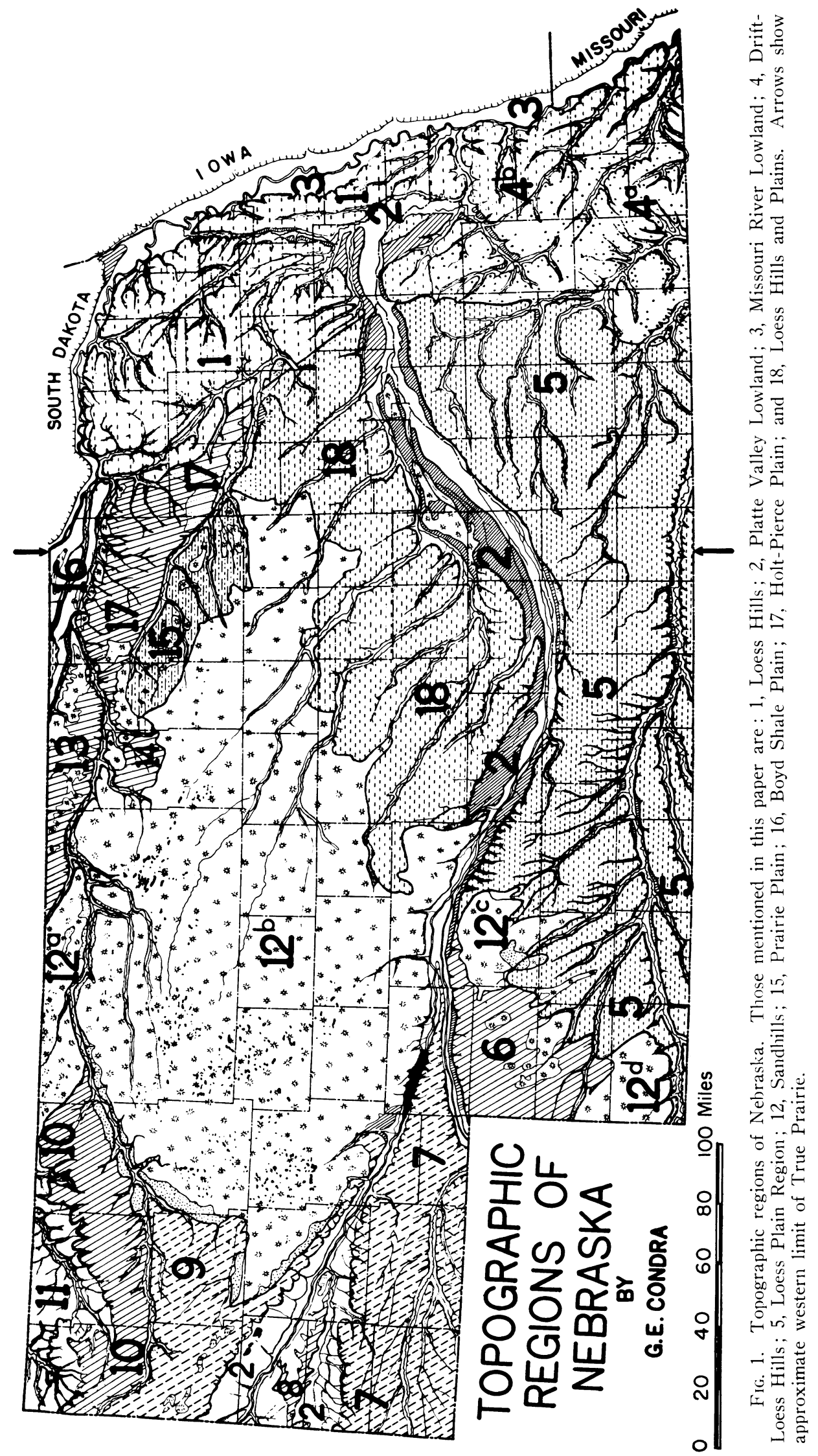




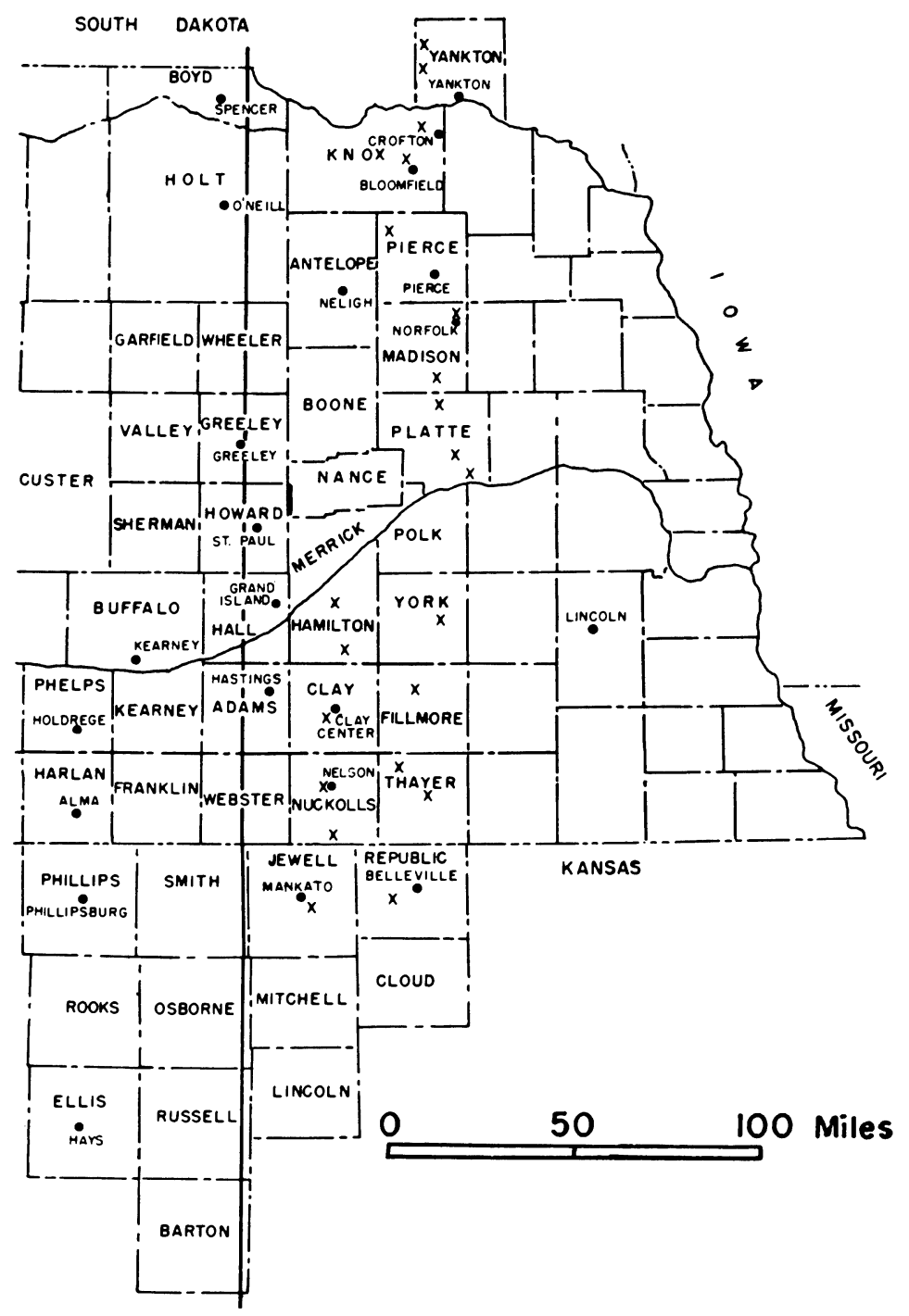

FIG. 2. Eastern Nebraska and adjacent areas with locations of counties, cities and towns mentioned in the text. Stations where extensive early studies were made are indicated by $x$. The heavy north-south line $\left(98^{\circ} 30^{\prime} \mathrm{W}\right.$ longitude) in the area of transition from True Prairie to Mixed Prairie represents the approximate place in which this change occurs.

to 16 inches tall at the first group of stations but 11 to 14 at the second. Similar differences occurred in 1929 and 1930 and were observed many times in following years. Big bluestem and switchgrass (Panicum virgatum) became much less widely distributed and showed no marked tendency toward the replacement of little bluestem as occurs eastward.

Fewer stems within the bunches of little bluestem and prairie dropseed (Sporobolus heterolepis) were commonly found westward. This indicated less favorable conditions for growth. In these drier grasslands, the base of the bunch was often only one-third to one-half occupied by green shoots. In well watered grassland eastward, 75 to 95 per cent of the area of the clump was normally completely filled with stems. Moreover, the small number and dwarfed appearance of flower stalks was a characteristic feature of these drier prairies except in the wettest years. The sod formed by big bluestem was much more open than were the usual dense stands elsewhere, and other vegetation was not so completely excluded by dense shade. This was also usually true of the sod of western wheatgrass (Agropyron smithii), hereafter designated as wheatgrass. Foliage cover on both uplands and lowlands was always reduced westward. The decrease was often 20 to 
25 per cent or more compared with extreme eastern Nebraska. This was reflected in the yields of hay which became smaller as the cover became more open and the grasses more dwarfed.

\section{Composition of the Grass Cover}

On the nearly level land, little bluestem usually dominated but it was commonly intermixed with 5 to 15 per cent of big bluestem. These percentages were ascertained by extensive sampling by meter quadrats more than a quarter of a century ago. Little bluestem remained dominant over much of the terrain where ordinarily one would expect to find big bluestem. Where the land locally was slightly lower and received run-in water, the percentage of big bluestem increased accordingly until finally rather pure open stands occurred. Its turning reddish brown and often drying in summer, sometimes over considerable areas, revealed the rather unstable water supply. Many poorly drained uplands supported big bluestem where small depressions occurred. Conversely, a slight rise in the topography often resulted in nearly pure little bluestem, the bunches becoming more pronounced and more widely spaced.

Westward, blue grama (Bouteloua gracilis) and buffalo grass (Buchloe dactyloides) gradually appeared between the bunches and later became intermingled as an understory to little bluestem. Where an additional water supply was afforded, as in depressions on hillsides or on protected north slopes and in ravines, the bluestem grasses, switchgrass and nodding wild rye (Elymus canadcnsis) formed limited areas of vegetation. In places, prairie dropseed and tall dropseed $(S$. asper) were both common to abundant, and only an occasional bunch of sand dropseed ( $S$. cryptandrus) occurred. Needle grass (Stipa spartea), formerly much more abundant, was found rather sparingly in 1928-34. Indian grass (Sorghastrum mitans) occurred in 1-3 per cent abundance, switchgrass was usually not plentiful, but June grass (Koeleria cristata) and Scribner's and Wilcox' panic grasses (Panicum scribnerianum and $P$. wilcoxianum) were widely distributed. Wheatgrass, scattered sparingly through the prairie, often occupied considerable areas on compact soils, especially those with claypans, sometimes to the exclusion of nearly all other vegetation. The rapidity with which these western True Prairies degenerated into short-grass pastures under grazing was quite in contrast to the gradual change from prairie to bluegrass pastures eastward.

Changes in the area of transition occurred gradually but widely. Density of short grasses between the bunches of little bluestem and prairie dropseed greatly increased and gradually reduced the bluestem to a second rate species and nearly or entirely replaced the dropseed. Needle-andthread (Stipa comata) became prominent while needle grass declined. Tall dropseed often lost its rank as a dominant, which was assumed by sand dropseed. Side-oats grama (Bouteloua curtipendula) took on rapidly increasing importance. June grass, though dwarfed, remained a species of considerable abundance. Wheatgrass thrived with reduced competition for light. Lowgrowing, drought-resistant sedges flourished in the sun as did various annual grasses.

On rolling to hilly land little bluestem mostly prevailed. Some dry knolls and steep xeric slopes were clothed with short grasses or mixtures of these with wheatgrass. Sand dropseed often became plentiful and dry slopes had patches and streaks of side-oats grama. The distinctly bunchtype of little bluestem in dry places changed to the tufted sod-mat where runoff water supplemented precipitation on mid or lower slopes. Little bluestem became intermixed with a considerable percentage of big bluestem only on the lower slopes or in ravines. Often on lowland, big bluestem was the only dominant. It also occurred in slight depressions on hilltops and hillsides, sometimes spreading to form limited areas of open sod. Vegetation of rolling land included all the grasses of level land but in amounts that varied with the topography. In these dry prairies whether level or rolling, switchgrass, nodding wild rye, and slough grass (Spartina pectinata) found suitable habitats quite limited.

This presents a brief glimpse of the carpet of prairie grasses as it stretched ever westward mile after mile over mostly level land into a continuously more arid climate. But with increasing drought the pattern changed as the more mesic grasses were largely replaced by species common to mixed prairie.

\section{Change in Dominants}

At stations bordering the transition zone on the west, such as Phillipsburg, Alma and Holdrege, the dominance of grasses had rather completely changed. Blue grama and buffalo grass were the most important and occurred in continuous and sometimes nearly pure stands. Elsewhere they were found as an understory to side-oats grama, wheatgrass, needle-and-thread, June grass, and sand dropseed. Little bluestem frequently remained as a principal species. Associated species were red three-awn (Aristida longiseta), purple three-awn (A. purpurea), squirreltail (Sitanion hystrix), and various carices-penn sedge (Carex pennsylvanica), involute-leaf sedge (C. elcocharis) and thread-leaf sedge (C. fili- 
folia). Little barley (Hordeum pusillum), sixweeks fescue (Festuca octoflora), and false buffalo grass (Munroa squarrosa) were also characteristic species. Big bluestem, Indian grass, tall dropseed and other tall grasses were often found in deep, moist ravines. Thus the dominant mid grasses were of a more xeric type and the prominent understory of short grass, not found in true prairie, extended over much of the soil without the presence of a well-developed overstory of mid grasses.

\section{Changes in Forbs}

For clarity of description, forbs have thus far been omitted. They are an important part of the prairie. The increased xerophytism westward was revealed by the forbs by decrease in number of species, smaller stature, and the presence of western species. These changes became clear when one compared the forbs of the luxuriant prairies of Iowa, southeastern Nebraska, and northeastern Kansas with those in the general area of eastern Nebraska and adjacent Kansas. In the former upland areas from 65 to 90 species of forbs were usually observed in selected prairies, of about 40 to 60 acres in extent, by two men working in them for 2 to 3 hours. The lists were considerably shorter (45-60 species) in the westward area described. But in the two tiers of cointies bordering the transition only 25 to 38 species were thus readily observed.

These western prairies were not especially conspicuous because of the forb population. This was due in part to the dwarfness of the plants. Often they attained no more than half the height of similar species in eastern counties of Nebraska. Many of the taller and more conspicuous ones found eastward did not occur or were much less frequent. Examples of these were Euphorbia corollata L., Coreopsis palmata, Meibomia canadensis, M. illinoensis, Asclepias tuberosa, Rudbeckia hirta, Liatris pycnostachya Michx., Silphium perfoliatum, and Solidago rigidiuscula. Many others such as Fragaria virginiana, Gentiana puberula Michx., and Phlox pilosa were not present. Conversely, western species which were rarely seen eastward occurred in and beyond the transitional area. Conspicuous among these were Sideranthus spinulosus, Chrysopsis villosa, Gaura coccinea, Malvastrum coccineum, Allionia linearis, Solidago mollis, Astragalus plattensis Nutt., Callirhoe involucrata, Oxytropis lamberti, Lygodesmia juncea, Thelesperma gracile, Cirsium ochrocentrum, and certain species of cacti. Numerous species with plants greatly reduced in size occurred throughout, for example, Kuhnia glutinosa, Solidago glaberrima, Aster multiflorus and Psoralea argophylla.
Depressed Areas

This seemingly endless carpet of grass was not uninterrupted. Scattered throughout the nearly level prairie were depressed areas which were occupied by a very different type of vegetation. These varied greatly in size. Many were small, covering only one-fourth acre; others were 80 to 160 acres in extent. The largest were sometimes 1 to 3 miles long and 2 to 4 square miles in area. The smaller depressions were only a foot or two below the general soil level but the larger ones were depressed 10 to 15 feet. Depth of accumulated water varied greatly from year to year and from spring to autumn. The shallow depressions usually became dry by mid or late summer. In larger and deeper ones, water exceeded 3 feet in depth during wet seasons. These fresh water marshes were scattered thickly over the plain. It has been ascertained that they occupied an area of more than a hundred square miles (Condra 1939). Their origin is not definitely known and may, in part, date back to a time preceding the deposition of the Peorian loess. Soils with heavy and thick claypans have developed in these depressions, viz. Scott and Fillmore soils. The water seeps through the heavy soil, or more probably through great cracks formed by the shrinking of the clay, hence there is no accumulation of salts. In these places, which are more or less alternately wet and dry, only adapted species of plants can exist.

One of the more abundant species and one which gave the characteristic color tone to these depressions was Scirpus acutus Muhl. A dark blue to green or even brownish color prevailed where dense stands occurred in places where the water was more or less continuously deep. In shallower water, perhaps only 18 inches deep in spring but nearly absent in late summer, Eleocharis macrostachya grew thickly in tufts 12 to 18 inches high. This perennial gave the landscape a very dark blue-green appearance throughout the growing season. In less permanently wet zones, a paludose form of Persicaria muhlenbergii and Lophotocarpus calycinus were conspicuous emersed water plants. Here also Persicaria longistyla, with its conspicuous masses of pink flowers, alternated with Coreopsis tinctoria, which gave a yellow tone to the wet land in late summer. Species of the floating stage, but persisting in very shallow water, were various pondweeds (Potamogeton), Marsilea vestita, Bacopa rotundifolia. (Michx.) Wettst., Heteranthera peduncularis and Alisma subcordatum. Typha angustifolia, Scirpus americanus, and Eleocharis acicularis, were common. On the outer edges of the larger depressions especially, but scattered irregularly through the shallower 
ones were large amounts of Echinochloa crusgalli and Hordeum jubatum, and, in places, Phalaris arundinacea. Other species were Ammannia coccinea, $A$. auriculata, Cyperus acuminatus, Vernonia fasciculata, Lippia cuneifolia, Gratiola neglecta Torr., and Franseria discolor Nutt. These plants were subjected to great variations as regards water content of soil and soil aeration.

Wheatgrass either in rather pure stands or with an understory of short grasses often bordered the deeper depressions and sometimes formed extensive hay meadows. On others, the muddy slopes became clothed with buffalo grass and blue grama. All of these grasses during dry years invaded the depressions at least temporarily. On the outer edge, the zone of grasses gave way to prairie.

\section{Eastward Movement of Mixed Prairie During Drought}

The remarkable panorama of change from one association of grassland to another was vividly portrayed on a grand scale during the terrible drought years, 1933-1941. On the westward border of the ecotone, the loss of mid and tall grasses and the gradual reduction of a typical area of Mixed Prairie to short grasses without the impact of grazing was studied during a period of seven years. The midgrasses-even the droughtresistant side-oats grama-succumbed and short grasses alone remained (Albertson and Weaver 1946). It was illustrative of a very widely spread phenomenon that occurred during that decade.

On the eastern border, the replacement of True Prairie by Mixed Prairie occurred as a result of the great drought in an area 100 to 150 miles in width in central Kansas, eastern Nebraska, and eastern South Dakota. The changes of plant populations and structure of vegetation were described in detail as they occurred in 1934 to 1941 in three widely separated native prairies (Weaver 1943). Predrought vegetation consisted mostly of the bluestems with only small amounts of wheatgrass, side-oats grama, blue grama, and buffalo grass. The chief dominant, little bluestem, mostly or entirely succumbed to drought in 1934 and 1936. Big Bluestem was greatly damaged. It finally disappeared in 1940. Wheatgrass rapidly increased each year; side-oats grama spread only temporarily. A steady increase and wide distribution of blue grama, and buffalo grass in a smaller degree, occurred throughout the drought. By simultaneous invasions of wheatgrass and short grasses, typical Mixed Prairie became clearly apparent in 1938. After seven years of drought, these grasslands were almost entirely transformed into Mixed Prairie. At this time, the entire transition region westward was also Mixed
Prairie. Thus, not only in the ecotone between these two great grassland associations, but in True Prairie as well, Mixed Prairie moved far eastward along a front more than a thousand miles in length.

\section{Partial Recovery Following Drought}

With the end of the drought and replacement of deep soil moisture resulting from abnormally heavy rains-sometimes 7 to 10 inches in a single month-, a reverse movement of the prairie migration began. This has been studied yearly at several, permanent, predrought stations. The most important finding was that the recovery of True Prairie of this invaded area was remarkably slow. Wheatgrass and short grasses spread rapidly over prairie where the former occupants had succumbed to drought. But bluestems, prairie dropseed, and others species had to regain areas already occupied.

After twelve years, Mixed Prairie still prevailed over two-thirds of the land it had invaded during the seven years of drought. Wheatgrass with an understory of short grasses, mostly blue grama, or extensive areas of short grasses without an overstory, composed the bulk of the vegetation. The wheatgrass stands were rather open, since wherever blue grama occurred, it decreased the density of the wheatgrass sod, lessened heightgrowth, and reduced production of flower stalks. Side-oats grama was nearly always an important component of the vegetation in both of the preceding types. As in drought, hairy chess (Bromus commutatus) grew thickly in these drier grass types and also occurred, although less abundantly, with big bluestem. Little bluestem was infrequent, but where it did occur it was increasing its area slowly. It had largely been replaced by big bluestem which now covered approximately a third of the prairies. It was best-developed on north-facing, steep slopes and on banks of ravines, but it also occurred elsewhere, always forming a rather open sod. In places, it was intermixed with wheatgrass, and a slow invasion of blue grama was clearly apparent in places. Eastward, two or three years were required to completely shade out the bordering short grass (Weaver 1954).

Forbs had greatly recovered and were fairly abundant in some of the prairies; in others they were relatively few in both species and numbers, except certain of the more xeric types such as Solidago glaberrima, S. mollis, and Kuhnia glutinosa. But the change from Mixed to True Prairie will require a long period of time for its completion. Nature is slow but persistent. Finally, it seems clear, she will put back upon these prairies those species that were there in the first 
place-long before the drought. The writers have seen this happen over a considerable area eastward (Weaver 1954).

\section{Transitional Area tfter Twelve Years FOR RECOVERY}

Anong the many prairies examined in the four counties of the transitional area in 1953 (Fig. 2), all were distinctly of the Mixed Prairie type. On the level land. blue grama, usually with small but sometimes with fairly large amounts of buffalo grass, dominated either alone or as an understory to wheat grass. These two species always composed most of the regetation and sometimes practically all of it. Penn sedge was extremely wide-spread and often very abundant. Patches and bunches of tall dropseed were found in most prairies and side-oats grama was an important and widely distributed micl grass. June grass was scattered more or less throughout. Wilcox' panic grass was plentiful in places: sand dropseed. plains muhly, purple lovegrass (Eragrostis spectabilis) and red three-awn usually occurred only in small amounts. Hairy chess, was wellrepresented and often it was abundant. On the level land, little bluestem was usually not present or at least only rarely, but big bluestem occurred in bunches or scattered small patches, but never abundantly.

Special mention should be made of the regetation southward on the rough land along the breaks of the Republican River (Fig. 1). Here, there are many thousands of acres of grassland. a part of which is used for the production of hay. Upland regetation was similar to that described. But that of the lower hillsides and canyons often benefited from favorable slope exposure. On well-protected lower and even mid slopes relatively small areas of little bluestem were found, with big bluestem occupying the ravines and the bases of slopes. But the patches and streaks of blue grama in the stand of little bluestem indicated a xeric habitat. Where the bluestem community occurred on upland, the grasses grew in sandy soil.

Erosion had produced canyons with steep banks that reached a height of 10 to 25 feet above the level bottom. These were partially protected from wind and sun and in addition they received runoff water from the surrounding upland. Anount of bluestems that occurred, especially big bluestem with a sprinkling of Indian grass, switchgrass, and nodding wild rye, varied from a wide belt, intermingled with a few shrubs, to a narrow strip of mesic vegetation including certain prairie forbs not generally distributed here. Often side-oats grama almost alone clothed the abrupt slopes or at least their upper rim. Rarely did big bluestem extend across the flat bottoms, although a ribbon-like area often demarked the course along which the water ran after heavy showers. Wheatgrass and short grasses, usually occupied the bottom, typically with an abundance of hairy chess, and often extended part way if not entirely up the slopes. Great variations in vegetation occurred with differences in the exposure of canyon walls and bottom to wind and sun. But the general vegetation in this transitional area remained Mixed Prairie.

\section{Transitional Area ix Kansas}

A thorough examination of many prairies was made in Smith, Osborne, Russell, and Barton counties in Kansas, which extend southward more than halfway across the state to the Arkansas River (Fig. 2). Topography varied from nearly level to rolling. and along the breaks of streams to hilly land. Soil type (Hastings-Hol(lrege Series) was the same as that in Nebraska and normal precipitation was 23 to 24 inches. There was much pasture land, and mowed prairies were easily located. Practically every grasscovered area examined was distinctly of the Mixed Prairie type. In nearly all, there was a more or less continuous cover of short grasses. The dominant micl grasses were side-oats grama, wheatgrass, tall dropseed, June grass, plains mulhly, and sand dropseed. Bluestems and Indian grass were often closely confined to ravines and ravine banks, but even these were sometimes clothed with tall dropseed or wheatgrass. In places, the bluestems occurred on steep north slopes, but in limited and open stands. On level land, big bluestem, especially, was found in depressions, intermixed with side-oats grama, but elsewhere its bunches were spaced well apart and usually surrounded by short grasses. Only on rocky hills, which were not plentiful, did True Prairie occur. Here impermeable rocks tend to raise the moisture supply of the intervening soil masses (Bates 1928).

The local effect of topography on vegetation was sometimes beautifully illustrated. In certain long, gently sloping ravines water supply in the shallow ditch was sufficient to support sloughgrass and a border of switchgrass with nodding wild rye. Where heavy rains occasionally caused the water to spread two or three rods laterally, bluestems and Indian grass occurred. Then abruptly, where the slope gently ascended, a carpet of short grasses and side-oats grama was spread, with bunches of bluestems scattered through it only on the lower slope. Typical Mixed Prairie covered the hillsides and hilltops. 
From these and numerous earlier observations, it seems certain that the area of transition in Kansas lies due south of that thus far described in Nebraska.

\section{Transition in the Loess Hills and Plains}

The transitional area between True and Mixed Prairie vegetation continues northward in $\mathrm{Ne}$ braska through the central portion of the Loess Hills and Plains (Fig. 1). The general physiography of this area is that of an upland plain, ranging from almost level to steeply rolling or hilly land. Over its greater part, the plain has been thoroughly dissected and is now hilly. The hills are often 100 to 150 feet higher than the valleys between them. Comparatively level land is not extensive. Grand Island and St. Paul are located along the line of transition. Sandy areas occur where the Platte Valley Lowland extends northeastward (Fig. 1). These somewhat obscure any change in grassland communities. But soon loess hills prevail which, like those westward, are clothed with excellent short grass on the tops and upper slopes, and short grass with an overstory of mid grass on the mid and lower slopes. Typical postclimax prairie vegetation is confined to the ravines where run-in water supplements the rather low annual precipitation of 23 inches. About 48 per cent or a total of 2,250 square miles of the upland loess soils of the four major counties in the central portion of the region is covered with the native prairie sod.

The vegetation of this mixed prairie area was first described in 1948 by Weaver and Bruner but soil surveyors in 1926 emphasized "the dense growth of grama and buffalo grass," red threeawn, wheatgrass, and bluestems. The several communities or types of Mixed Prairie were delimited and described and the clominant and subdominant species ascertained. Hopkins (1951) studied the extent, composition, and environment of each prairie type. "The short-grass and mixed-grass types were of approximately equal extent in the entire area; each covered an average of about 33 per cent of all the prairie areas." He ascertained that blue grama composed $91 \%$ of the vegetation in the more xeric community and buffalo grass only about 5\%. Chief components of the mixed-grass community were blue grama $50 \%$, side-oats grana 18\%, big bluestem $8 \%$ (largely replacing the little bluestem lost in the drought), species of sedges $7 \%$, and wheatgrass $4 \%$. Species of western grasses and forbs were common throughout. In general, these were the same as those found on the Mixed Prairie already described for the Loess Plain Region. The postclimax associes of mid and tall grasses was found on steep sides of ravines and in moist lowland. Big bluestem, especially, sometimes grew in bunches or in open stands on well-protected north and northeast hillsides. Composition of the vegetation (Hopkins 1951) was big bluestem (56\%), side-oats grama $(13 \%)$, various sedges $(11 \%)$ and western wheatgrass $(2 \%)$. Total area occupied by this type was approximately $27 \%$. The manner in which the mid and tall grasses were replaced by short grasses, as a result of grazing, has been shown by Branson and Weaver (1953). Travelling north from the central loess hills one passes through the sandhills and enters the Prairie Plain.

\section{Prairie Plain}

The land is nearly level except for the occasional occurrence of sand hills. The ground water lies near the soil surface over most of the area. The subirrigated meadlows of the broad valleys are a western extension of lowland True Prairie. The hydric vegetation varies from that of ponds and small lakes, which are abundant, through wet meadow, to the big bluestem type of grassland. Keim et. al. (1932) have shown that the structure of this vegetation is closely correlated with the depth to the water table. Over much of the Prairie I'lain, the wet meadow type prevails. There is little if any difference in the lowland vegetation here and in the valley of the Elkhorn River at Neligh and Norfolk, in the True Prairie eastward. Moreover, the same wet prairie type extends far northwestward into the Mixed Prairie climate. From the Sand Hills, soil water for subirrigation supplements the precipitation. Consequently, the vegetation throughout its extent reveals practically no change in climate. But there is a marked change in vegetation after one crosses the Elkhorn Valley and enters the Holt-Pierce Plain.

\section{Holt-Pierce Plain}

The area of transition across this plain is characterized mostly by level or rolling land. But there are also some sandhills, and breaks occur along the Niobrara River and its tributaries. Areas of deep sandy soil characterized by sand reed (Calamozilfa longifolia) are extensive but infrequent. On the less sandy land covered by 18 to 30 inches of fertile black soil, which is most characteristic of the region, the vegetation revealed its Mixed Prairie nature. Where the soils were intermixed with sand, the higher and drier areas were clothed with Mixed Prairie vegetation and the wetter lowland with an open type of True Prairie postclimax. The following examples are illustrative. 
A prairie near O'Neill, on level land with two feet of black soil overlying sand, consisted of about 85 per cent blue grama and 5 per cent buffalo grass. There was no continuous overstory. Scattered small patches of sand reed and bunches of big bluestem occurred. Little bluestem was rare but side-oats grama, sand dropseed, red threeawn, and a half dozen other plains and prairie grasses were present. Forbs more abundant eastward, such as Artemisia gnaphalodes, Solidago glaberrima, and Psoralea argophylla, mingled with more western ones, Allionia linearis, Chrysopsis villosa, Opuntia fragilis (Nutt.) Haw. Neomamillaria vivipara (Nutt.) Britton and Rose, Hedeoma hispida, and abundant Plantago purshii.

Conversely, on vast stretches of sand plains, needle grass or needle-and-thread either alone or intermixed, constituted 80 to 95 per cent of the vegetation. Where blue grama formed an understory on more compacted soil, these grasses were thinned, sometimes to a very light stand. Little bluestem, sandlill bluestem, sand reed, June grass, purple three-awn, but only a very small amount of big bluestem were accompanying species. A sand flora of non-grasses was intermixed with many species of True Prairie in these transitional grasslands.

On intermediate soil types, slope exposure and ru11-in water caused great variations in distribution of regetation. But even where postclimax. lowland prairie occurred, the stand of bluestems was far less dense and other vegetation much more open than in prairies eastward on tinis plain or at Pierce, Bloomfield. and Crofton (Fig. 2.). An extensive examination revealed clearly that the region of transition from True to Mixed Prairie passes through the central portinn of the Holt-Pierce Plain. Upon crossing the Niobrara River, one enters the Boyd Shale Plain.

\section{Boyd Suale Plain}

Prairies selected for study were all located on the level or sloping land characteristic of the general topography. Here the normal precipitation as at O'Neill, is about 22 inches. The steep bluffs of the deeply channeled Niobrara and of the Ponca River afforded many sheltered and wellwatered habitats which resulted in a westward extension of True Prairie grassland. On typical, nearly level areas of "hard land," blue grama with some buffalo grass formed an almost continuous layer of vegetation. The upper story consisted of wheatgrass, side-oats grama, and sand dropseed, all abundant. Only infrequently were the bluestems found and then always in slight depressions. Extending outward a short distance from broad shallow ravines with run-in water. open stands of big and little bluestem intermixed with side-oats grama, various sedges and Kentucky bluegrass, occurred. There was often an understory of short grasses. The clayey nature of the soil was indicated by the presence of slough grass in the wettest places, a species rarely found in the loess hills.

In other prairies on rolling land, strips of True Prairie grasses and forbs bordered the lower parts of the more protected slopes. Extending from the ribbon of slough grass in the wet ravine bottoms to the top of the ravine banks, they usually gave way, often abruptly, to mixed prairie. Here the short grasses were overtopped by wheatgrass and side-oats grama or they occurred between the bunches of little and big bluestem scattered sparingly over the hillsides. On crests of hills and those with broad level tops, the bluestems and more mesic forbs were absent. Here the short grasses prevailed or short grass with wheatgrass and side-oats grama. Representative forbs from both true and mixed prairie were found. They were most abundant and the societies more pronounced on the less xeric sites. Chief societies were Amorpha canescens, Artemisia gnaphalodes, Psoralea argophylla, Echinacea pallida. Solidago mollis. Sideranthus spinulosus, Ratibida columnaris, and Artemisia frigida.

Another type of vegetation common on many hard lands was that of blue grama under a thick overstory of needle-and-thread. Sicle-onts grama was usually common. Other grasses lightly intermixed were needle grass, June grass, penn sedge and other sedges, red three-awn, and plains mulhly. Little bluestem was not common but bunches and patches of open sod of big bluestem grew in slight depressions or where run-in water supplemented the supply furnished by an approximate 22 inches of precipitation. This type of Mixed Prairie prevailed over the hills and uplands: only in the deeper ravines was it replaced by True Prairie. In other prairies, belts and patches of True Prairie vegetation with its characteristic plant societies, alternated with even larger fragments of Mixed Prairie with its similarly distinctive forbs of the plains.

From these data one must conclude that a transitional area where True Prairie vegetation gives way to that of the drier Mixed Prdirie occurs in the eastern part of the Boyd Shaje Plain (Fig. 2).

\section{Summary}

The very gradual changes in vegetation from True to Mixed Prairie have been described. These occur over a broad ecotone about 50 miles in width as shown in Figures 1 and 2. If the 
place were to be indicated by a single line, one (98 $30^{\prime} \mathrm{W}$ longitude) extending along the eastern side of Barton County to Smith County in Kansas, and through Hastings, Grand Island, and Greely to O'Neill and Spencer in Nebraska (Fig. 2 ) would be representative.

\section{ReFERENCES}

Albertson, F. W. 1937. Ecology of mixed prairie in west central Kansas. Ecological Monog. 7: 481-547.

Albertson, F. W., and J. E. Weaver. 1946. Reduction of ungrazed mixed prairie to short grass as a result of drought and dust. Ecological Monog. 16: 449-463.

Bates, C. G. 1928. The special problems of forest soils. Proc. and Papers, First Intern. Cong. Soil Sci. 4-5: 566-574.

Branson, F. W., and J. E. Weaver. 1953. Quantitative study of degeneration of mixed prairie. Bot. Gaz. 114: $397-416$.

Britton, N. L., and A. Brown. 1913. An illustrated flora of the northern United States, Canada, and the British Possessions. 2nd ed. New York Bot Gard., New York. 3 vols.

Clements, F. E. 1920. Plant indicators. Carnegie Inst. Wash. Pub. 290.
Clements, F. E., and J. E. Weaver. 1924. Experimental vegetation. Carnegie Inst. Wash. Pub. 355.

Condra, G. E. 1939. An outline of the principal natural resources of Nebraska and their conservation. Univ. Nebr. Conserv. and Surv. Div. Bull. 20.

Hitchcock, A. S., and A. Chase. 1950. Manual of the grasses of the United States. 2nd ed. U. S. Dept. Agr. Misc Pub. 200.

Hopkins, H. H. 1951. Ecology of the native vegetation of the loess hills in central Nebraska. Ecological Monog. 21: 125-147.

Keim, F. D., A. L. Frolik, and G. W. Beadle. 1932. Studies of prairie hay in north central Nebraska. Neb. Expt. Sta. Res. Bull. 60.

Weaver, J. E. 1943. Replacement of true prairie by mixed prairie in eastern Nebraska and Kansas. Ecology 24: 421-434.

- 1954. A seventeen-year study of plant succession in prairie. Amer. Jour. Bot. 41: 31-38.

Weaver, J. E., and W. E. Bruner. 1948. Prairies and pastures of the dissected loess plains of central $\mathrm{Ne}$ braska. Ecological Monog. 18: 507-549.

Weaver, J. E., and T. J. Fitzpatrick. 1934. The prairie. Ecological Monog. 4: 109-294. 